\title{
PENGEMBANGAN STRATEGI PEMBELAJARAN BERBASIS MASALAH UNTUK MENINGKATKAN KETERAMPILAN BERPIKIR KRITIS DAN KEMAMPUAN PEMECAHAN MASALAH PESERTA DIDIK
}

\author{
Alwi $^{1}$, Tabrani Gani ${ }^{2}$, Muhammad Danial ${ }^{3}$ \\ ${ }^{1}$ Guru Kimia SMAN 3 Bone \\ ${ }^{2,3}$ Dosen Program Pascasarjana Universitas Negeri Makassar \\ Email: alwikimia@gmail.com
}

\begin{abstract}
ABSTRAK
Tujuan penelitian ini adalah merancang strategi pembelajaran berbasis masalah untuk meningkatkan keterampilan berpikir kritis dan kemampuan pemecahan masalah peserta didik. Mengembangkan strategi pembelajaran berbasis masalah diyakini lebih efektif diterapkan dalam pembelajaran kimia. Pembelajaran konvensional diyakini menjadi salah satu permasalahan kegagalan peserta didik. Hal ini menjadikan peserta didik berperan pasif dalam pembelajaran. Peneliti merumuskan dua pertanyaan penelitian sebagai berikut: (1) Bagaimana gambaran pengembangan strategi pembelajaran berbasis masalah yang dapat meningkatkan keterampilan berpikir kritis dan kemampuan pemecahan masalah peserta didik? (2) Bagaimana gambaran kualitas strategi pembelajaran berbasis masalah yang dikembangkan ditinjau dari kevalidan, kepraktisan, dan keefektifannya? Penelitian ini adalah penelitian dan pengembangan yang terdiri dari identifikasi, perancangan, pengembangan, dan implementasi. Identifkasi kebutuhan pembelajaran dihasilkan berdasarkan pengamatan selama proses pembelajaran untuk membuat prototipe strategi pembelajaran kemudian dilakukan uji coba untuk mendapatkan desain strategi pembelajaran dengan melakukan pretest-posttes di SMAN 3 Bone. Dalam pengumpulan data peneliti menggunakan angket, lembar pengamatan dan tes. Angket diberikan 35 peserta didik di tahun pelajaran 2018/2019. Instrumen yang digunakan dalam penelitian ini divalidasi oleh para ahli yang terkait di bidangnya. Hasil penelitian menunjukkan bahwa pengembangan strategi pembelajaran berbasis masalah dapat meningkatkan keterampilan berpikir kritis dan kemampuan pemecahan masalah peserta didik SMAN 3 Bone. Para guru dan peserta didik Di SMA 3 Bone menganggap bahwa strategi pembelajaran berbasis masalah praktis dan efektif untuk diimplementasikan dalam pembelajaran kimia.
\end{abstract}

Kata kunci : strategi pembelajaran, berpikir kritis, pemecahan masalah.

\begin{abstract}
The study aims at designing problem-based learning strategy to improve critical thinking skill and problem solving ability of students. Developing problem-based learning strategy is believed to be more effective to be applied in Chemistry learning. The convensional learning is believe to be a problem which creates failure to students. It make studens being passive in leaning. The researcher formulates two research question as follow: (1) How is the description of the development of problem-based learning strategy that able to improve critical thinking skilla and problems solving ability of students? (2) How is the description of the quality of problem-based learning strategy developid based on validity, practicality, and effectivenes? This study is research and development, which consists of identification, design, development, and implementation. Identification of learning needs is generated based on observation during the learning process to make a prototype learning strategy; then, conduct a trial to get the disign of learning strategies by doing the pretest-posttest at SMAN 3 Bone. In
\end{abstract}


collecting the data, the researcher employs questionnaire, observation sheet, and test. Questionnaires were given to 35 students of academic year 2018/2019. The instrumen used in this study were validated by experts related to their field of studies. The results of the study reveal that the development of problem-based learning strategy can improve critical thinking skill and problem solving ability of $s$ tudents at SMAN 3 Bone. Teachers and students at SMAN 3 Bone considered that the problem-based learning strategy is practical and effective to be applied in Chemistry learning.

Keywords: learning strategies, critical thinking, problem solving.

\section{PENDAHULUAN}

Kemajuan ilmu pengetahuan dan teknologi turut mewarnai dunia pendidikan kita dewasa ini, tantangan tentang peningkatan mutu, relevansi, dan efektivitas pendidikan sebagai tuntutan nasional sejalan dengan perkembangan dan kemajuan masyarakat, berimplikasi secara nyata dalam program pendidikan dan kurikulum sekolah. Proses pembelajaran yang diselenggarakan di sekolah berlandaskan pada kurikulum 2013. Kurikulum 2013 menginginkan proses pembelajaran yang lebih berpusat pada peserta didik untuk mengembangkan kreativitas, menciptakan kondisi yang menyenangkan, menantang dan kontekstual (Irmayanti, 2015). Hal inilah yang menuntut proses pembelajaran untuk selalu mengubah konsep berpikir peserta didik. oleh karena itu dalam proses pembelajaran tidak hanya sekadar mentransfer pengetahuan ke peserta didik, namun harus melibatkan proses kognitif secara aktif sehingga peserta didik dapat memahami dengan baik konsepkonsep yang disampaikan oleh guru melalui proses berpikir rsecara mendalam dan tingkat tinggi. Proses berpikir secara mendalam tersebut salah satunya dengan berpikir kritis agar dapat mengkrontruksi pengetahuannya sehingga lebih baik lagi.

Salah satu masalah dalam pembelajaran kimia adalah belum efektifnya penyajian materi atau strategi pembelajaran yang di laksanakan oleh guru. Implikasinya tampak dalam proses pembelajaran dimana peserta didik belum berperan aktif memikirkan masalah yang berhubungan kehidupan sehari-harinya. Peserta didik belum mampu menemukan informasi yang dibutuhkan dalam pembelajaran. Peserta didik belum mampu memikirkan situasi yang kontekstual dan menyajikan solusi dari masalah yang ada. Selanjutnya peserta didik belum mampu membangun pengetahuan sendiri, mengembangkan keterampilan berpikirnya serta kemampuan pemecahan masalah. Proses pembelajaran di kelas masih berada pada kemampuan mengingat segala dimensi pengetahuan yang disajikan oleh guru tanpa mereka dituntun bagaimana memahami dimensi pengetahuan yang diingatnya.

Masalah lain dalam pembelajaran kimia adalah peserta didik masih memiliki pemahaman konsep yang rendah terhadap pengetahuan kimia. Pengetahuan akan konsep-konsep kimia lebih banyak diperoleh melalui hafalan sehingga berdampak pada rendahnya kemampuan peserta didik dalam menganalisis materi pembelajaran. Kenyataan ini terjadi karena peserta didik belum biasa dilatih bagaimana berpikir pada tingkat menganalisis. Peserta didik masih kesulitan menghubungkan pengetahuan yang dimiliki dengan fenomena dalam kehidupan sehari-hari. Metode penyajian materi lebih banyak mengaktifkan guru daripada peserta didik sehingga keterampilan berpikir dan kemampuan pemecahan masalah pembelajaran tidak berkembang. Sari (2012), menyatakan bahwa dalam pembelajaran di kelas saat diberikan pertanyaan, hanya beberapa peserta didik yang menjawab pertanyaan dari guru. Peran serta peserta didik dalam proses pembelajaran masih kurang, yakni hanya sedikit yang menunjukkan keaktifan berpendapat dan bertanya. Pertanyaan yang dibuat peserta didik belum menunjukkan 
pertanyaan-pertanyaan kritis berkaitan dengan materi yang dipelajari. Tingkat jawaban dari pertanyaan guru masih sebatas ingatan dan pemahaman saja, belum ada jawaban yang menunjukkan tingkat analisis.

Fakta-fakta tersebut di atas juga terjadi di SMA Negeri 3 Bone. Hasil pengamatan peneliti pada proses pembelajaran ditemukan beberapa masalah yaitu; (1) peserta didik kurang aktif memikirkan konsep-konsep materi pembelajaran, sehingga belum memperoleh pemahaman dari konsep tersebut, (2) peserta didik kurang mampu menemukan informasi yang dibutuhkan dalam pembelajaran, sehingga belum mampu memecahkan masalah yang ada, (3) peserta didik kurang mampu menghubungkan materi-materi konseptual dengan masalah yang ada dalam kehidupan sehari-hari, sehingga tingkat pengetahuan yang dimiliki masih berada pada tingkat mengingat atau menghafal. Tingkat pengetahuan yang masih rendah diyakini dapat membuat pembelajaran belum efektif sehingga kecermatan penguasaan perilaku yang dipelajari belum mampu tercapai. Hal tersebut juga akan memberikan pengaruh terhadap perolehan hasil berlajar seperti pada ujian nasional.

Data hasil Ujian Nasional tiga tahun berturut-turut dari Pusat Penilaian Pendidikan Balitbang Kemdikbud (2018), yaitu SMA Negeri 3 Bone memperoleh nilai rata-rata mata pelajaran IPA 69,11 dan nilai rata-rata untuk SMA se Kabupaten Bone 62,06. Data tersebut menunjukkan bahwa nilai ujian nasional kimia peserta didik yang merupakan bagian dari IPA berada pada kategori rendah di bawah nilai KKM 75. Nilai ujian nasional merupakan gambaran dari hasil belajar peserta didik selama mengikuti program pendidikan di SMA. Selanjutnya hasil wawancara dengan beberapa guru di SMA Negeri 3 Bone tentang strategi pembelajaran, penulis mendapatkan informasi bahwa guru memiliki pemahaman yang berbeda mengenai strategi pembelajaran. Sebagian guru memahami strategi pembelajaran itu adalah model, pendekatan, dan metode yang digunakan dalam proses pembelajaran dan adapula yang memahaminya sebagai langkah-langkah dan cara melaksanakan pembelajaran.

Fakta-fakta tersebut di atas menunjukkan beberapa kelemahan pada pembelajaran kimia. Untuk itu perlu upaya perbaikan sehingga kelemahan ini tidak menghambat tercapainya tujuan pembelajaran kimia ke depannya. Salah satu upaya perbaikan yang mampu dilakukan adalah menerapkan strategi pembelajaran yang tepat untuk meningkatkan efektivitas pembelajaran. Salah satu strategi pembelajaran yang sesuai kurikulum 2013 adalah pembelajaran berbasis masalah (PBM). PBM adalah pembelajaran yang diawali dari masalah-masalah yang ditemukan dalam kehidupan sehari-hari. Sebelum peserta didik mempelajari suatu hal, mereka diharuskan mengidentifikasi suatu masalah, baik yang dihadapi secara nyata maupun telaah kasus. Masalah diajukan sedemikian rupa sehingga para siswa menemukan kebutuhan belajar yang diperlukan agar mereka mampu memecahkan masalah tersebut. Abidin (2014), menyatakan bahwa strategi PBM mampu memfasilitasi peserta didik untuk berperan aktif di dalam kelas melalui aktivitas memikirkan masalah yang berhubungan kehidupan sehari-harinya. Peserta didik mampu menemukan informasi yang dibutuhkan dalam pembelajaran, memikirkan situasi yang kontekstual, memecahkan masalah, dan menyajikan solusi dari masalah tersebut. Strategi ini juga membantu guru mengembangkan keterampilan berpikir kritis dan pemecahan masalah dari peserta didik.

Wahyuni (2015), menyatakan bahwa berpikir kritis merupakan suatu bentuk pemikiran yang berusaha memahami masalah secara mendalam, memiliki pemikiran terbuka terhadap keputusan dan pendapat orang lain, berusaha mengerti dan mengevaluasi secara benar informasi yang diterima sebelum mengambil keputusan 
serta mampu menghubungkan antara sebab dan akibat dalam menemukan pemecahan masalah yang dihadapi. Keterampilan berpikir kritis menciptakan kemampuan kognitf tingkat tinggi sehingga peserta didik lebih mudah menganalisis konsep-konsep pengetahuan kimia yang bersifat abstrak menjadi lebih kentekstual.

Kesetimbangan kimia merupakan salah satu materi yang banyak mengandung konsep-konsep abstrak seperti: konsep kesetimbangan dinamis, tetapan kesetimbangan dan faktor-faktor yang mempengaruhi kesetimbangan. Hal ini membuat peserta didik sulit memahami dan cenderung hanya menghafal konsep yang ada. Untuk membantu mengatasi kesulitan tersebut diperlukan strategi pembelajaran berbasis masalah melalui penyajian konsep yang lebih kontekstual dimana masalah dalam kehidupan nyata dikaitkan dengan materi pembelajaran.

Hasil penelitian yang dilakukan oleh Sari (2012), diperoleh bahwa kemampuan berpikir kritis peserta didik di kelas VIII B SMP Negeri 5 Sleman mampu ditingkatkan melalui penerapan model Problem Based Learning. Hasil penelitian tersebut menegaskan bahwa pembelajaran berbasis masalah juga diyakini dapat diterapkan dalam pembelajaran kimia.

Keterampilan berpikir kritis dan kemampuan pemecahan masalah adalah suatu kemampuan kognitif peserta didik. Hal tersebut akan ditingkatkan melalui suatu pengembangan strategi pembelajaran berbasis masalah yang diintegrasikan ke dalam sintaks PBM. Pengembangan strategi PBM mencakup urutan kegiatan pembelajaran, metode dalam penyampaian materi, media untuk menyampaikan pesan dan pengalokasian waktu pembelajaran. Keseluruhan komponen strategi PBM tersebut dilaksanakan pada setiap tahapan pembelajaran PBM. Stategi PBM diharapkan mampu menyediakan pengalaman otentik yang mendorong peserta didik untuk belajar aktif, berpikir secara kritis, mengonstruksi pengetahuan, dan mengingtegrasikan konteks belajar di sekolah ke dalam kehidupan sehari-hari. Peserta didik terlibat secara langsung dalam memecahkan masalah, mengidentifikasi akar masalah dan kondisi yang diperlukan untuk menghasilkan solusi yang baik, mengejar makna dan pemahaman, dan menjadi pebelajar mandiri.

Berdasarkan pemaparan diatas strategi pembelajaran berbasis masalah diharapkan dapat mengaktifkan peserta didik dalam proses pembelajaran pada materi kesetimbangan kimia di SMA Negeri 3 Bone. Peserta didik diharapkan lebih memahami konsep-konsep yang diperoleh dari pembelajaran berbasis masalah melalui proses berpikir ilmiah sehingga dapat mengaitkan hubungan antara konsep yang satu dengan konsep yang lainnya dan digunakan untuk mengetahui struktur kognitif peserta didik. Struktur kognitif yang terbentuk diyakini dapat meningkatkan keterampilan berpikir kritis dan kemampuan pemecahan masalah pada materi kesetimbangan kimia. Berdasarkan hal tersebut, saya tertarik untuk meneliti "Pengembangan Strategi Pembelajaran Berbasis Masalah untuk Meningkatkan Keterampilan Berpikir Kritis dan Kemampuan Pemecahan Masalah Peserta didik".

\section{METODE PENELITIAN}

Penelitian ini adalah penelitian dan pengembangan (Research and Development) yang bertujuan mengembangkan strategi pembelajaran kimia berbasis masalah pada materi kesetimbangan kimia yang dapat meningkatkan keterampilan berpikir kritis dan kemampuan pemecahan masalah peserta didik. Penelitian dan pengembangan strategi pembelajaran berbasis masalah mengacu pada model Dick and Carey (1990) yang terdiri dari empat tahap yaitu identifikasi, perancangan, pengembangan, dan implementasi.

Tahapan mengidentifkasi kebutuhan pembelajaran berupa kompetensi dasar pada silabus mata pelajaran kimia. Identifikasi ini bertujuan untuk mengetahui kompetensi dasar dengan perolehan nilai yang masih 
rendah. Adapun acuan untuk mengidentifikasi kebutuhan pembelajaran dalam penelitian ini adalah dokumentasi nilai Ujian Nasional selama tiga tahun terakhir dari peserta didik SMA Negeri 3 Bone.

Identifikasi perilaku awal peserta didik berupa kemampuan awal yang dimiliki sehubungan dengan materi kesetimbangan kimia. Kegiatan mengidentifikasi perilaku awal peserta didik didasarkan pada pengamatan peneliti selama mengampu mata pelajaran kimia di SMA Negeri 3 Bone. Sedangkan identifikasi karakteristik peserta didik adalah kebiasan atau gaya belajar peserta didik. Penilaian gaya belajar peserta didik menggunakan angket gaya belajar yang dimodifikasi dari J. Diana Connel dalam Yaumi (2013). Angket terdiri atas 24 item pernyataan dengan pembagian 8 item untuk masing-masing gaya belajar visual, kinestetis, dan auditori. Pada setiap item penyataan, peserta didik memberikan tanda ceklis pada kolom (2) apabila pernyataan tersebut sama, (1) apabila hampir sama, (0) apabila tidak sama dengan kebiasaan dan kesukaan peserta didik.

Pada tahapan ini dirancang strategi pembelajaran pada setiap tujuan pembelajaran yang telah dirumuskan. Penyusunan strategi pembelajaran meliputi uraian aktivitas pembelajaran, metode, media atau alat pembelajaran, dan alokasi waktu pembelajaran. Uraian aktivitas pembelajaran terdiri atas tiga tahapan yakni pendahuluan, penyajian, dan penutup. Tahapan pendahuluan meliputi deskripsi singkat materi pelajaran, relevansi materi pelajaran dengan materi sebelumnya, dan penyampaian tujuan pembelajaran. Tahap penyajian mengikuti fase atau tahapan model pembelajaran berbasis masalah yang meliputi orientasi peserta didik pada masalah, mengorganisasikan peserta didik dalam belajar, membimbing penyelidikan individual maupun kelompok, mengembangkan dan menyajikan hasil karya, dan menganalisis dan mengevaluasi proses pemecahan masalah. Selanjutnya tahap penutup meliputi umpan balik dan tindak lanjut. Pemilihan metode dan media berdasarkan karakteristik perilaku pada tujuan pembelajaran, sedangkan pengalokasian waktu berdasarkan volume kegiatan pada setiap tahapan pembelajaran. Kegiatan ini merupakan kegiatan akhir dari tahap perancangan. Hasil yang diperoleh pada tahapan ini disebut desain awal strategi pembelajaran (prototipe 1). Selanjutnya desain awal dikembangkan melalui melalui penyususnan perangkat pembelajaran, validasi ahli dan tahap uji coba.

Pada tahapan implementasi, hasil pengembangan (produk) strategi pembelajaran berbasis masalah disebarkan kepada beberapa guru pada sekolah yang sama maupun sesama anggota MGMP kimia Kabupaten Bone. Adapun tujuan yang dari tahap ini adalah guru dapat menggunakan produk dalam proses pembelajaran kedepannya sehingga penyampaian pembelajaran lebih efektif dan efisien. Selain itu guru juga diharapkan memberikan penilaian dan saran terhadap produk ini sehingga lebih menyempurnakan kualitas dari hasil pengembangan pada penelitian ini.

\section{HASIL DAN PEMBAHASAN}

Langkah awal dalam merancang dan mengembangkan pembelajaran adalah mengidentifikasi kebutuhan pembelajaran. Identifikasi dan analisis kebutuhan yang dimaksudkan adalah mengetahui kompetensi yang harus dikuasai oleh peserta didik. Dalam pelajaran kimia SMA kompetensikompetensi ini dikenal dengan istiliah kompetensi dasar (KD) yang telah dirumuskan dalam silabus mata pelajaran kimia. Kompetensi dasar hasil identifikasi akan dicapai pada pembelajaran semester ganjil.

Hasil identifikasi terhadap pencapaian kompetensi dasar mata pelajaran kimia SMA semester ganjil yaitu, perolehan nilai dari kompetensi dasar tersebut masih rendah. Hal ini diketahui dari data hasil ujian nasional tiga tahun berturut-turut dari Pusat Penilaian Pendidikan Balitbang 
Kemdikbud (2018), yaitu SMA Negeri 3 Bone memperoleh nilai rata-rata mata pelajaran IPA 69,11 dan nilai rata-rata untuk SMA se Kabupaten Bone 62,06. Nilai ini menunjukkan bahwa penguasaan konsep peserta didik pada kompetensi mata pelajaran kimia masih rendah dan perlu upaya perbaikan pada kegiatan pembelajarannya. Berkaitan dengan hal ini, ada dua kompetensi dasar yang menjadi perhatian yaitu, (1) Menjelaskan reaksi kesetimbangan dalam hubungan antara pereaksi dan hasil reaksi, dan (2) Menganalisis faktor-faktor yang mempengaruhi pergeseran arah kesetimbangan dan penerapannya dalam industri. Kedua kompetensi dasar tersebut akan dicapai melalui pembelajaran materi kesetimbangan kimia. Setelah mengetahui kebutuhan pembelajaran dan kompetensi yang perlu ditingkatkan dari peserta didik, selanjutnya dilakukan identifikasi terhadap kemampuan atau perilaku khusus yang mendukung pencapaiannya, keterampilan yang dibutuhkan, dan kegiatan pembelajaran yang harus dilakukan.

Hasil identifikasi kebutuhan pembelajaran peserta didik yang telah dilakukan pada tahap sebelumnya diperoleh informasi bahwa komptetensi dasar yang perlu upaya perbaikan dalam pencapaiannya adalah KD pada materi kesetimbangan kimia. Dalam materi kesetimbangan kimia memuat beberapa kemampuan atau perilaku khusus yang perlu dimiliki peserta didik agar dapat melakukan semua kemampuan yang diharapkan pada materi pembelajaran.

Pada tahapan ini dlakukan identifikasi perilaku awal atau kemampuan awal peserta didik yakni sejauh mana pengetahuan dan keterampilan yang telah dikuasai oleh peserta didik sehingga mereka dapat mengikuti kegiatan pembelajaran selanjutnya. Berdasarkan pengamatan peneliti selama mengampu mata pelajaran kimia, dapat dijelaskan bahwa peserta didik baru memiliki sebagian kecil pemahaman konsep tentang kesetimbangan kimia. Hal ini dimungkinkan karena peserta didik sudah mengikuti kegiatan pembelajaran laju reaksi dimana materi ini menjadi pengetahuan pendukung untuk pembelajaran kesetimbangan kimia.

Identiffikasi karakteristik peserta didik adalah ciri peserta didik yang diasumsikan dapat menunjang pencapaian tujuan pembelajaran. Salah satu karakteristik peserta didik yang diperhatikan dalam pengembangan strategi pembelajaran ini adalah gaya belajar peserta didik. Gaya belajar dikelompokkan menjadi tiga bagian yakni visual, auditori, dan kinestetik.

Hasil identifikasi gaya belajar peserta didik dengan menggunakan angket diperoleh bahwa $42,86 \%$ peserta didik dominan memiliki gaya belajar visual, $42,86 \%$ dominan memiliki gaya belajar kinestetis, dan $14,28 \%$ dominan memiliki gaya belajar auditori (lihat lampiran 4.2). Data ini menjadi pertimbangan dalam memilih metode dan media pembelajaran pada strategi pembelajaran yang dikembangkan. Peserta didik dengan gaya belajar visual akan lebih mudah memahami jika dapat melihat secara langsung proses atau situasi yang terjadi. Gaya belajar ini dapat menggunakan alat bantu melalui presentasi powerpoint atau melihat langsung proses yang terjadi melalui eksprimen. Peserta didik dengan gaya belajar auditori lebih senang belajar melalui pendengaran. Jenis gaya belajar ini menyukai penyajian materi melalui ceramah yakni guru memberikan penjelasan verbal kepada peserta didik tentang topik atau masalah yang dibahas. Peserta didik dengan gaya belajar kinestetik lebih senang melakukan aktivitas belajar secara fisik, mereka senang melakukan atau mendemonstrasikan sendiri daripada mendengarkan. Memperhatikan gaya belajar yang dimiliki oleh peserta didik yang didominasi gaya belajar visual dan kinestetik maka dalam pengembangan strategi pembelajaran berbasis masalah dipilih beberapa metode seperti eksprimen, tanya jawab, diskusi, dan ceramah yang dibantu dengan media berupa powerpoint, lembar kerja peserta didik, dan buku peserta didik. 
Hasil identifikasi perilaku awal peserta didik pada tahap sebelumnya diperoleh gambaran bahwa peserta didik sudah memiliki pengetahuan awal tentang materi kesetimbangan kimia. Selanjutnya dilakukan perumusan tujuan pembelajaran berdasarkan hasil identifikasi awal peserta didik. Tujuan pembelajaran dipahami sebagai deskripsi dari suatu kemampuan atau perilaku yang diinginkan untuk mampu ditunjukkan oleh peserta didik sebelum guru menganggap mereka kompeten. Tujuan pembelajaran merupakan pernyataan yang mencakup tiga domain yakni sikap, pengetahuan, dan keterampilan yang ingin dikuasai oleh peserta didik setelah menyelesaikan pembelajaran. Tiga domain belajar yang mencakup domain sikap yang merujuk pada perasaan, domain pengetahuan yang menekankan tingkatan berpikir, serta domain keterampilan yang menekankan pada tindakan. Keseluruhan hal tersebut merupakan pijakan dasar dalam merumuskan tujuan pembelajaran.

Rumusan tujuan pembelajaran harus menggunakan kata kerja spesifik yang dapat diukur. Adapun kata kerja domain pengetahuan yang digunakan dalam merumuskan tujuan pembelajaran dari $\mathrm{KD}$ kesetimbangan kimia yaitu: menjelaskan, membedakan, menyimpulkan, menghitung dan memilih. Menjelaskan dan menyimpulkan adalah perilaku kognitif pada level memahami, menghitung merupakan perilaku kognitf pada level mengaplikasi. Sedangkan membedakan dan memilih adalah perilaku kognitif pada level menganalisis.

Kata kerja domain psikomotorik juga manjadi bagian dalam penelitian ini. Adapun kata kerja domain psikomotorik dalam merumuskan tujuan pembelajaran pada KD menyajikan hasil pengolahan data untuk menentukan nilai tetapan kesetimbangan suatu reaksi serta KD merancang, melakukan, dan menyimpulkan serta menyajikan hasil percobaan faktor-faktor yang mempengaruhi pergeseran kesetimbangan diantaranya adalah: menyajikan, merancang, melakukan, dan menyimpulkan.

Berdasarkan tujuan pembelajaran yang telah dirumuskan pada tahap sebelumnya, maka dilakukan analisis pembelajaran yang merupakan tahapan untuk mengetahui pengetahuan dan keterampilan yang harus dicapai terlebih dahulu oleh peserta didik. Analisis ini untuk membantu melihat arah kegiatan pembelajaran secara bertahap menuju pencapaian tujuan pembelajaran. Hal ini mengurangi kemungkinan pencapaian tujuan pembelajaran yang tidak runut dan pemberian isi pelajaran yang tidak relevan. Analisis pembelajaran akan menggambarkan susunan perilaku khusus dari yang paling awal hingga yang paling akhir sehingga pencapaian tujuan pembelajaran dapat efektif dan efisien.

Tes merupakan alat penilaian hasil belajar atau pemahaman konsep peserta didik. Alat penilaian yang disusun harus konsisten dan relevan dengan perilaku yang harus diukur sebagaimana yang telah dirumuskan dalam tujuan pembelajaran. Skor yang diperoleh peserta didik dalam tes hasil belajar ditafsirkan sebagai tingkat penguasaannya terhadap kompetensi yang diukur. Dengan demikian penafsiran dari hasil tes mencerminkan tingkat penguasaan peserta didik terhadap kompetensi yang terdapat pada tujuan pembelajaran. Selanjutnya strategi pembelajaran yang dikembangkan pada penelitian ini menggunakan alat penilaian berupa tes tertulis yang tercantum dalam bagian penilaian RPP.

$\begin{array}{cccc}\text { Dari } & \text { hasil rumusan tujuan } \\ \text { pembelajaran } & \text { dan } & \begin{array}{c}\text { tahapan analisis } \\ \text { tanan }\end{array}\end{array}$ pembelajaran diperoleh deskripsi tentang urutan perilaku khusus yang harus dimiliki peserta didik untuk mencapai setiap tujuan pembelajaran. Tahapan selanjutnya adalah merancang prototipe strategi pembelajaran untuk mencapai setiap tujuan pembelajaran yang telah dirumuskan. Tahapan ini meliputi penyajian materi pembelajaran dalam setiap tahap pembelajaran berbasis masalah, 
pemilihan metode pembelajaran, media pembelajaran dan penentuan alokasi waktu setiap tahap pembelajaran.

Penyusunan RPP diawali dengan rancangan strategi pembelajaran yang merupakan produk utama dari penelitian ini. Strategi pembelajaran dirancang dan dikembangkan ke dalam RPP. Berdasarkan alokasi waktu pembelajaran untuk KD menjelaskan reaksi kesetimbangan dalam hubungan antara pereaksi dan hasil reaksi serta KD menganalisis faktor-faktor yang mempengaruhi pergeseran arah kesetimbangan dan penerapannya dalam industri (delapan jam pelajaran), maka keenam tujuan pembelajaran dibagi ke dalam empat RPP (empat kali pertemuan) sesuai dengan struktur kompetensinya. tujuan pembelajaran 1 dan 2 merupakan satu kelompok (cluster) kompetensi yang saling berhubungan sehingga dikelompokkan dalam satu RPP yakni RPP pertemuan pertama. tujuan pembelajaran 3 dan 4 juga satu kelompok kompetensi yang berhubungan sehingga dimuat dalam RPP kedua, dan selanjutnya tujuan pembelajaran 5 dan 6 masing-masing terpisah dalam RPP ketiga dan keempat.

Format RPP yang disusun adalah: (1) kompetensi inti, (2) kompetensi dasar dan indikator pencapaian kompetensi, (3) tujuan pembelajaran, (4) materi pembelajaran, (5) model, pendekatan, dan metode pembelajaran, (6) media pembelajaran, (7) strategi pembelajaran, dan (8) penilaian. Keempat RPP tersebut dapat dilihat dalam lampiran 11.

Lembar kerja peserta didik merupakan salah satu media dalam kegiatan pembelajaran. Penyusunan LKPD berdasarkan tujuan pembelajaran yang akan dicapai pada setiap pertemuan atau disesuaikan dengan rancangan RPP pada setiap pertemuan dengan tujuan untuk membantu peserta didik mencapai tujuan yang diharapkan. Setiap LKPD dilengkapi dengan tujuan pembelajaran dan pengantar teori. Tujuan pembelajaran memuat rumusan kemampuan atau prilaku yang dapat dilakukan oleh peserta didik setelah kegiatan pembelajaran. Pengantar teori sebagai deskripsi singkat dan acuan bagi peserta didik dalam membangun pengetahuan tentang konsep yang akan dipelajari. LKPD juga disusun dengan tujuan melatih dan mengembangkan keterampilan berpikir kritis (KBK) dan kemampuan pemecahan masalah (KPM) peserta didik dalam pembelajaran. Pengembangan KBK dan KPM dalam LKPD melalui tahapan-tahapan pemecahan masalah yang dilengkapi dengan pertanyaan-pertanyaan tingkat analisis sehingga peserta didik dapat belajar dan melatih diri membangun konsep serta prosedur dalam memecahkan masalah secara sistematis.

Tahapan implementasi merupakan tahapan akhir dari seluruh proses pengembangan strategi pembelajaran berbasi asalah. Berdasarkan tahapan sebelumnya (tahap pengembangan) diperoleh hasil pengembangan berupa produk strategi pembelajaran berbasis masalah yang telah melalui proses validasi dan uji coba. Pada tahapan ini, hasil pengembangan ditindaklanjuti dengan melakukan diseminasi ke guru-guru sesama sekolah dan anggota MGMP Kimia untuk mendapat masukan atau saran tentang penerapan strategi PBM guna penyempurnaan dari hasil penelitian ini.

Berdasarkan hasil diseminasi kebeberapa guru kimia, diperoleh data bahwa produk strategi PBM dapat dijadikan acuan dalam pembelajaran kimia khususnya materi kesetimbangan. Selain itu juga diperoleh saran bahwa produk strategi ini hendaknya melengkapi pertanyaanpertanyaan konseptual pada LKPD dan BPD khususnya pada tahapan pembelajaran merumuskan permasalahan agar peserta didik lebih mudah merumusakan permasalahan yang bersifat kontekstual.

Sebagaimana telah dikemukakan sebelumnya bahwa penelitian ini termasuk jenis penelitian dan pengembangan yang bertujuan untuk mengembangkan suatu strategi pembelajaran serta menghasilkan produk strategi pembelajaran yang dapat digunakan dalam pembelajaran untuk 
meningkatkan keterampilan berpikir kritis dan kemampuan pemecahan masalah peserta didik

Pada bagian ini dikemukakan pembahasan hasil penelitian mengenai ketercapaian tujuan penelitian yaitu (1) Proses pengembangan strategi pembelajaran berbasis masalah, dan (2) Kualitas produk strategi PBM yang valid, praktis dan efektif.

Proses pengembangan strategi PBM ini menggunakan model pengembangan Dick and Carey. Tahapan pertama yang dilakukan adalah mengidentifikasi kebutuhan pembelajaran melalui identifikasi tujuan instruksional umum (KD) agar diperoleh informasi tentang kompetensi peserta didik yang harus ditingkatkan. Pada tahap ini dilakukan studi dokumentasi hasil belajar peserta didik yaitu nilai ujian nasional tiga tahun terakhir. Hasil yang diperoleh yaitu penguasaan konsep kimia peserta didik masih rendah berdasarkan nilai ujian nasional dengan rata-rata 69,11. Berdasarkan identifikasi tersebut, KD yang harus ditingkatkan adalah materi kesetimbangan kimia. Selanjutnya hasil tersebut menjadi dasar dalam melakukan analisis pembelajaran untuk mengetahui kemampuan yang harus dicapai terlebih dahulu oleh peserta didik. Untuk mengetahui pengetahuan apa yang sudah dimiliki tentang kesetimbangan kimia, maka dilakukan identifikasi perilaku awal peserta didik melalui pretes. Dari kegiatan pretest terhadap 35 peserta didik diperoleh kemampuan awal peserta didik masih rendah, karena belum ada peserta didik yang memperoleh nilai di atas KKM 75. Kegiatan akhir dari tahap ini adalah identifikasi karakteristik awal peserta didik yaitu gaya belajar melalui angket yang diberikan. Angket gaya belajar berfungsi agar peneliti memperoleh informasi tentang kebutuhan belajar peserta didik terutama dalam penentuan metode dan media pembelajaran. Hasil angket gaya belajar diperoleh bahwa peserta didik lebih dominan pada gaya belajar visual dan kinestetik. Artinya peserta didik akan mudah meningkatkan pemahaman konsepnya dalam pembelajaran melalui aktivitas yang dialami langsung seperti mengamati informasi dengan media visual atau melakukan eksprimen.

Tahap kedua adalah tahap perancangan. Pada tahap ini dilakukan perumusan tujuan pembelajaran materi kesetimbangan kimia dengan menetapkan beberapa kemampuan atau perilaku yang akan dicapai oleh peserta didik setelah pembelajaran. Adapun perilaku yang ditetapkan yaitu menjelaskan, membedakan, menyimpulkan, menghiutng, dan memilih yang mana semuanya masuk pada level kognitif menganalisis. Dengan tercapainya kemampuan menganalsis, maka peserta didik diharapkan memiliki keterampilan berpikir kritis dan kemampuan pemecahan masalah di dalam pembelajaran. Untuk mengetahui tercapainya tujuan pembelajaran maka dilakukan penyusunan item tes yang akan digunakan dalam proses dan akhir pembelajaran. Kegiatan berikutnya pada tahapan ini adalah merancang strategi pembelajaran sebagai prototipe pertama dalam penelititan ini. Perancangan strategi pembelajaran melalui pemilihan metode pembelajaran yaitu metode ceramah, telaah informasi, tanyajawab, diskusi, penugasan, dan eksprimen. Selanjutnya pemilihan media pembelajaran yang disesuaikan dengan perilaku yang akan dicapai pada tujuan pembelajaran yaitu media lembar kerja peserta didik, buku peserta didik, liquid crystal display, lembaran, dan abesensi. Penentuan alokasi waktu pembelajaran dilakukan dengan cara menyesuaikan jumlah aktivitas peserta didik pada setiap tahapan pembelajaran sehingga waktu yang jumlahnya terbatas dapat digunkan dengan tepat untuk mencapai tujuan pembelajaran.

Tahap ketiga adalah pengembangan. Pada tahap in diawali dengan penyusunan perangkat pembelajaran RPP dan LKPD. Perangkat yang telah disusun kemudian dilakukan penilaian oleh ahli untuk mengetahui tingkat kevalidannya. Selanjutnya dilakukan uji coba terbatas terhadap strategi PBM yang telah dirancang 
agar dapat meningkatkan keterampilan berpikir kritis dan kemampuan pemecahan masalah peserta didik. Ujicoba dilakukan pada peserta didik kelas XI MIA 1 SMA Negeri 3 Bone yang berjumlah 35. Hasil uji coba ini bertujuan untuk mengetahui tingkat kualitas dari produk strategi PBM yang telah dikembangkan. Selama pelaksanaan ujicoba, peneliti melibatkan dua orang pengamat dari guru SMA Negeri 3 Bone yang sudah berpengalaman dibidangnya.

Tahap keempat adalah implementasi. Pada tahapa ini diperoleh data bahwa produk strategi pembelajaran dapat dijadilan acuan dalam pembelajaran kimia pada materi kesetimbangan kimia. Hal ini dapat dijelaskan bahwa produk strategi pembelajaran berbasis masalah sudah memuat keseluruhan rencana tindakan dalam pembelajaran yang terdiri atas, urutan aktivitas pembelajaran, penetapan metode pembelajaran, pemilihan media yang sesuai tujuan pembelajaran, serta pengalokasian waktu berdasarkan jenis dan karakteristik dari kemampuan atau perilaku yang akan dicapai oleh peserta didik.

Berdasarkan penilaian dua orang ahli dibidang pendidikan kimia teradap strategi pembelajaran berbasis masalah yang terintegrasi dalam RPP yang dilengkapi dengan media berupa LKPD dan BPD, diperoleh hasil penilaian rata-rata masingmasing 3,72 untuk RPP, 3,75 untuk LKPD, dan 3,66 untuk BPD. Sesuai kriteria validitas oleh Nurdin (2007), penilaian ini menunjukkan ketiga produk ini memenuhi kategori sangat valid $(3,5 \leq M \leq 4)$ sehingga layak digunakan dalam proses pembelajaran di kelas untuk uji coba.

Kevalidan produk ini tidak lepas dari saran dan masukan dari validator ahli. Beberapa saran yang diberikan dalam RPP seperti mencantumkan keterampilan berpikir kritis dan kemampuan pemecahan masalah yang dapat dilatihkan dan dikembangkan pada setiap tahap pembelajaran. Selain itu diberikan pula masukan agar pembagian waktu pada setiap tahap pembelajaran secara proporsional dan disesuaikan dengan volume kegiatan pada tahapan itu. Dalam
LKPD validator ahli menyarankan agar pertanyaan dibuat secara terstruktur sehingga peserta didik dapat belajar tentang tahapan mengontruksi suatu konsep dan jawaban pertanyaan tersebut tidak terdapat dalam pengantar teori pada LKPD. Pertanyaan terstruktur dapat melatih keterampilan berpikir kritis dan kemampuan pemecahan masalah peserta didik.

Pada tahap uji coba di kelas, komponen strategi pembelajaran yang tidak dapat terlaksana sesuai yang telah ditetapkan adalah komponen waktu. Komponen ini sangat dipengaruhi oleh kondisi peserta didik. Kemampuan peserta didik memahami permasalahan yang dibahas menjadi menyebab pemakaian waktu yang lebih dari yang telah ditetapkan. Ketika banyak peserta didik mengajukan pertanyaan maka membutuhkan waktu yang banyak pula. Kondisi ini tentunya tidak bisa dihentikan secara spontan karena hal ini menunjukkan rasa antusiasme peserta didik dalam belajar.

Kepraktisan produk strategi pembelajaran yang dirancang dapat diukur dari tiga hal yakni: pertama, penilaian pengamat terhadap kemampuan guru melaksanakan pembelajaran kedua, hasil penilaian terhadap respon guru dan ketiga, aktivitas guru terhadap strategi pembelajaran berbasis masalah. Masing-masing instrumen menggunakan lembar pengamatan dan bagi instrumen respon guru menggunakan angket yang semua telah divalidasi oleh tim ahli dibidang pendidikan kimia.

Penilaian tim ahli terhadap instrumen pengamatan tersebut pada aspek tujuan, isi, dan bahasa memiliki nilai rata-rata total 3,75. Sesuai kriteria penilaian $(3,5 \leq M \leq 4)$, nilai ini menunjukkan bahwa instrumen pengamatan kemampuan guru sangat valid sehingga layak untuk digunakan mengukur kepraktisan strategi pembelajaran berbasis masalah.

Pengamatan terhadap kemampuan guru dilakukan oleh dua pengamat, dimana keduanya merupakan guru kimia SMA Negeri 3 Bone yang berpengalaman pada mata pelajaran yang diampunya. Hasil penilaian dari kedua pengamat terhadap 
pelaksanaan aspek pembelajaran yaitu penyajian materi, metode, media, penggunaan waktu, dan suasana kelas memberikan nilai rata-rata 1,89 . Sesuai kriteria kemampuan guru oleh Nurdin (2007) yakni $(1,5 \leq \mathrm{M} \leq 2,0)$ menunjukkan bahwa guru melaksanakan strategi pembelajaran berbasis masalah sangat baik karena aspek-aspek pembelajaran terlaksana seluruhnya. Penilaian ini diperkuat oleh komentar pengamat dalam lembar pengamatan bahwa proses pembelajaran telah berlangsung sesuai skenario pembelajaran dalam RPP. Situasi lain yang tuliskan oleh pengamat dalam pembelajaran peserta didik sangat tertarik dan bersemangat dalam berdiskusi. Satu hal yang perlu dikontrol adalah penggunaan waktu.

Respon guru terhadap strategi pembelajaran berbasis masalah melalui pemberian komentar yang menyatakan bahwa secara umum strategi pembelajaran yang dirancang dan pemilihan metode sangat mudah dilaksanakan dalam proses pembelajaran. Ketersedian media dan lembar kerja peserta didik dapat menciptakan kondisi bagi peserta didik untuk membangun makna dan menentukan informasi yang dibutuhkan dalam pembelajaran. Selanjutnya rubrik penilaian yang terdapat dalam RPP yang terdiri atas penilaian kognitif, psikomotorik dan sikap sangat membantu guru dalam menilai aspekaspek prilaku dalam pembelajaran. Namum demikian masih ada hal yang dianggap sulit untuk dikontrol oleh guru yaitu penggunaan waktu pada setiap langkah pembelajaran. Hasil respon dari guru ikut menguatkan pernyataan bahwa strategi pembelajaran yang dirancang sangat praktis untuk dilaksanakan dalam pembelajaran kimia di kelas khususnya materi kesetimbangan kimia.

Kepraktisan mengimplementasikan strategi pembelajaran ini terdapat pada lembar kerja peserta didik (LKPD). Dalam LKPD sangat jelas langkah-langkah dalam mengembangkan keterampilan berpikir kritis dan pemecahan masalah yang harus dilakukan oleh peserta didik, sehingga guru hanya mengarahkan atau bertindak sebagai fasilitator. Ungkapan ini juga didukung oleh pendapat beberapa orang peserta didik yang mempunyai nilai tinggi. Mereka mengungkapkan bahwa kemudahan dalam memahami materi karena pada LKPD tersusun secara sistematis pertanyaan yang harus dijawab sehingga peserta didik juga terlatih dan mengetahui cara-cara memecahkan suatu masalah. Peserta didik berharap agar setiap pembelajaran kimia menggunakan LKPD sehingga peserta didik terus melatih diri dalam memecahkan masalah-masalah kimia.

Berdasarkan hasil aktivitas guru, kriteria kepraktisan juga mengacu pada terlaksananya aktivitas guru minimal terhadap $70 \%$ aspek yang diamati. Artinya, delapan dari 11 aktivitas guru harus terlaksana.

Selama kegiatan pembelajaran dengan strategi PBM pada materi kesetimbangan kimia, pendidik melakukan kegiatan sesuai sintaks PBM sehingga membuat peserta didik terlibat aktif dan dominasi guru dalam pembelajaran dapat dikurangi. Dengan demikian dapat disimpulkan bahwa strategi PBM dapat mengoptimalkan peserta didik dalam pembelajaran sehingga lebih mandiri.

Kriteria keefektifan produk strategi pembelajaran meliputi: (1) Peningkatan keterampilan berpikir kritis, (2) Peningkatan kemampuan pemecahan masalah, Aktivitas peserta didik, dan (4) Respon peserta didik. Pembahasan hasil pengukuran keefektifan strategi pembelajaran berbasis masalah adalah sebagai berikut:

Berdasarkan deskripsi data keterampilan berpikir kritis peserta didik menunjukkan gambaran umum keterampilan berpikir kritis peserta didik baik sebelum dan sesudah pembelajaran. Pada Tabel 4.7 terlihat bahwa nilai tertinggi sesudah diberi pembelajaran lebih besar daripada sebelum diberi pembelajaran yaitu 100 untuk sesudah pembelajaran dan 52 untuk sebelum 
pembelajaran. Selain nilai tertinggi, nilai rata-rata sesudah pembelajaran juga lebih besar, yaitu 85,17 sedangkan sebelum pembelajaran sebesar 28,77. Hasil tersebut menunjukkan bahwa nilai rata-rata peserta didik sesudah pembelajaran dengan strategi PBM lebih tinggi daripada sebelum pembelajaran dengan selisih 56,40 poin. Peningkatan nilai rata-rata peserta didik sesudah pembelajaran dengan strategi PBM menunjukkan bahwa keterampilan berpikir kritis peserta didik sesudah pembelajaran lebih baik daripada sebelum pembelajaran.

Hasil pretest dan posttest yang mewakili 5 indikator keterampilan berpikir kritis yang terdiri dari beberapa subindikator yang ada di dalamnya, pada hasil posttest diperoleh rata-rata keterampilan berpikir kritisnya lebih tinggi daripada pretest. Indikator berpikir kritis yang pertama yaitu memberikan penjelasan sederhana, data yang diperoleh dari posttest sebesar $98,57 \%$ sedangkan pada pretest sebesar $53,71 \%$. Indikator berpikir kritis yang kedua yaitu membangun keterampilan dasar, data yang diperoleh pada posttest sebesar 98,90\% sedangkan pada pretest sebesar $42,01 \%$. Indikator berpikir kritis yang ketiga yaitu memberikan penjelasan lebih lanjut, data yang diperoleh dari posttest sebesar $83,64 \%$ sedangkan pada pretest sebesar $21,97 \%$. Indikator berpikir kritis yang keempat yaitu mengatur strategi dan taktik, data yang diperoleh pada posttest sebesar 81,00\% sedangkan pada pretest sebesar $28,77 \%$. Indikator berpikir kritis yang kelima yaitu menyimpulkan, data yang diperoleh pada posttest sebesar $65,41 \%$ sedangkan pada pretest sebesar $8,60 \%$. Pada indikator berpikir kritis yang kelima ini pada posttest yang diperoleh nilai presentase tergolong rendah karena kebanyakan peserta didik tidak menjawab semua soal dan kalaupun menjawab semua namun hasil perhitungannya salah sehingga pada saat menyimpulkan menjadi salah pula, pada item tes sebagian besar terdiri atas soal perhitungan dimana pembelajaran yang dilaksanakan lebih mengarah kepada konsep-konsep. Pembelajaran dengan konsep-konsep tersebut menyebabkan kurangnya contoh-contoh terutama pada soal perhitungan sehingga mempengaruhi kemampuan berpikir kritis peserta didik, serta sebelum menyimpulkan suatu permasalahan atau soal harus mengatur strategi dan taktik yang baik dan benarbenar matang agar menghasilkan kesimpulan yang baik dan benar. Tapi secara keseluruhan diperoleh keterampilan berpikir kritis peserta didik mengalami peningkatan yang terlihat dari persentase rata-rata tiap aspek ketermpilan berpikir kritis mengalami kenaikan.

Berdasarkan Tabel 4.8 dapat dilihat bahwa presentase rata-rata untuk setiap indikator keterampilan berpikir kritis mengalami peningkatan setelah pembelajaran dan terlihat juga dari nilai rata-rata faktor gain untuk semua aspek ketrampilan berpikir kritis sebesar 0,824. Hasil ini menunjukkan bahwa secara keseluruhan terjadi peningkatan keterampilan berpikir kritis setelah diterapkan strategi pembelajaran berbasis masalah. Selanjutnya strategi PBM juga membuat peserta didik mejadi lebih mandiri sehingga bisa mengasah keterampilan berpikirnya terutama berpikir kritis. Hasil analisis ini relevan dengan beberapa hasil penelitian terdahulu diantaranya, hasil uji peningkatan keterampilan berpikir kritis yang dilakukan oleh Rahma (2012) diperoleh hasil uji N-Gain keterampilan berpikir kritis dari pengembangan perangkat pembelajaran model inkuiri berpendekatan SETS dengan menggunakan model pengembangan 3-D termasuk dalam kategori tinggi dengan nilai $\mathrm{N}$-Gain sebesar 0,72 . Hasil uji peningkatan keterampilan berpikir kritis yang dilakukan juga oleh Wahyuni, Sri (2015) diperoleh hasil keterampilan berpikir kritis dari pengembangan bahan ajar dengan menggunakan model pengembangan 4-D menunjukan peningkatan KBK baik yang dimabil dengan teknik tes maupun pratikum. Berdasarkan dari teknik tes diperoleh hasil $75 \%$ peserta didik memiliki kemampuan berpikir kritis dan 7,5\% memiliki kemampuan sangat kritis. 
Kemudian hasil uji keefektifan yang dilakukan oleh Khotim, dkk (2015) diperoleh hasil uji $\mathrm{N}$-Gain hasil belajar peserta didik dari pengembangan modul berbasis masalah dengan menggunakan model 3-D termasuk dalam kategori sedang dengan nilai $\mathrm{N}-$ Gain sebesar 0,41 .

Hasil penelitian lainnya yang berhubungan dengan uji kefektifan yang dilakukan oleh Alfana, dkk (2015) diperoleh hasil uji N-Gain hasil belajar dan kemampuan berpikir kreatif peserta didik dari pengembangan LKS berbasis konstruktivisme dengan menggunakan model pengembangan 4 -D termasuk dalam kategori sedang dengan nilai $\mathrm{N}-$ Gain sebesar 0,52 .

Hasil analisis tentang kemampuan pemecahan masalah peserta didik sesuai tabel 4.10, diperoleh bahwa aspek mendefinisikan masalah berada pada kategori tinggi, aspek mengembangkan rencana untuk menyelesaikan masalah memperoleh kategori tinggi, aspek mengumpulkan dan menganalisis informasi memperoleh kategori sangat tinggi, dan aspek menafsirkan temuan dan memecahkan masalah juga memperoleh kategori tinggi. Selanjutnya rata-rata untuk seluruh aspek kemampuan pemecahan masalah berada pada kategori tinggi dengan skor 3,38 (3,0 $\leq$ $\mathrm{KPM} \leq 3,5=$ tingg). Capaian ini menunjukkan bahwa produk rancangan strategi pembelajaran berbasis masalah dapat meningkatkan kemampuan pemecahan masalah peserta didik.

Dalam kegiatan pembelajaran dengan strategi PBM, guru menciptakan kondisi dan memfasilitasi peserta didik agar lebih aktif mencari dan mengolah informasi yang dibutuhkan melalui LKPD dan BPD. Pada setiap tahapan pembelajaran berbasis masalah peserta didik dilatihkan kemampuan pemecahan masalah dengan cara guru menyajikan masalah diawal pembelajaran selanjutnya peserta didik melakukan aktivitas pemecahan masalah sesuai dengan langkah-langkah pemecahan masalah dalam LKPD.
Kriteria keefektifan selanjutnya adalah terlaksananya aktivitas peserta didik minimal terhadap $70 \%$ aspek yang diamati. Hal ini berarti dari 8 aktivitas peserta didik yang diamati, 6 diantaranya harus terlaksana. Berdasarkan hasil analisis data aktivitas peserta didik menunjukkan bahwa delapan kategori pada aktivitas peserta didik terpenuhi

Selama kegiatan pembelajaran dengan strategi PBM pada materi kesetimbangan kimia, peserta didik terlibat aktif sehingga dominasi guru dalam pembelajaran dapat dikurangi. Dengan demikian dapat disimpulkan bahwa strategi PBM dapat mengoptimalkan peserta didik dalam pembelajaran sehingga lebih mandiri.

Analisis lain yang mendukung keefektifan suatu produk pembelajaran adalah respon peserta didik terhadap pelaksanaan produk tersebut. Untuk mengetahui respon peserta didik terhadap pelaksanaan pembelajaran maka dirancang instrumen yang meliputi aspek ketertarikan, motivasi, keaktifan, rasa percaya diri, kemampuan memahami konsep, dan keterampilan proses kognitif. Hasil analisis pada aspek-aspek tersebut diperoleh ratarata nilai $52,65 \%$ peserta didik menyatakan sangat setuju (respon positif), 36,77\% menyatakan setuju (respon positif), 10,58\% menyatakan cukup setuju (respon negatif), dan tidak ada peserta didik yang menyatakan tidak setuju. Dan hasil analisis perolehan skor peserta didik terhadap skor maksimum diperoleh 29 peserta didik $(82,86 \%)$ kategori sangat merespon (respon positif) dan 6 peserta didik $(17,14 \%)$ kategori merespon (respon positif). Menurut Riduwan (2008), strategi pembelajaran dinyatakan efektif jika $80 \%$ peserta didik memiliki skor minimun pada kategori merespon (respon positif). Hasil respon peserta didik menunjukkan bahwa seluruh peserta didik merespon positif pelaksanaan strategi pembelajaran berbasis masalah. Hal ini sejalan yang dikemukakan oleh Moejiono (1993) dan Lalu (1993) bahwa strategi penemuan dapat meningkatkan kerjasama dan keterlibatan 
peserta didik secara aktif dalam memperoleh informasi, memotivasi rasa ingin tahu, mengembangkan keterampilan dan rasa percaya diri, mengembangkan kemampuan berpikir dan melatih daya nalar peserta didik.

Memperhatikan hasil pengukuran dari keempat instrumen di atas maka disimpulkan bahwa produk strategi pembelajaran berbasis masalah efektif dalam meningkatkan keterampilan berpikir kritis dan kemampuan pemecahan masalah peserta didik.

\section{SIMPULAN DAN SARAN}

Berdasarkan hasil penelitian dan pengembangan yang telah dilakukan, maka dapat disimpulkan:

Pertama, Proses pengembangan strategi pembelajaran berbasis masalah mengacu pada model Dick and Carey yang tahapannya meliputi: (1) Tahap identifikasi terdiri dari dua langkah yaitu mengidentifikasi kebutuhan pembelajaran (kompetensi dasar), dan mengidentifikasi perilaku awal dan karakteristik peserta didik, (2) Tahap perancangan terdiri dari empat langkah yaitu merumuskan tujuan pembelajaran, menganalisis pembelajaran, menyusun tes, dan merancang strategi pembelajaran, (3) Tahap pengembangan terdiri dari tiga langkah yaitu menyusun perangkat pembelajaran, validasi dari ahli dan uji coba rancangan produk yang dilakukan secara terbatas di SMA Negeri 3 Bone. Semua rancangan produk memenuhi kategori sangat valid berdasarkan validasi ahli, dan berdasarkan hasil uji coba memenuhi kategori praktis, serta efektif sehingga layak digunakan sebagai acuan dalam pembelajaran, (4) Tahap implementasi berupa diseminasi produk.

Kualitas strategi pembelajaran berbasis masalah yakni: (1) Sangat valid berdasarkan penilaian dari ahli dengan sedikit revisi. (2) Praktis karena guru dapat melaksanakan semua aspek pembelajaran dan seluruh aktivitas guru memenuhi interval toleransi yang dipersyaratkan. (3) Efektif karena peserta didik telah memiliki keterampilan berpikir kritis dan kemampuan pemecahan masalah pada kategori tinggi dan seluruh aktivitas peserta didik memenuhi interval toleransi yang dipersyaratkan serta peserta didik memberikan respon sangat positif terhadap strategi pembelajaran berbasis masalah

Strategi pembelajaran berbasis masalah dapat meningkatkan keterampilan berpikir kritis peserta didik dengan perolehan faktor $\mathrm{N}$-Gain sebesar 0,824 pada kategori tinggi.

Strategi pembelajaran berbasis masalah dapat meningkatkan kemampuan pemecahan masalah peserta didik dengan perolehan skor rata-rata semua aspek kemampuan pemecahan masalah sebesar 3,38 pada kategori tinggi.

Berdasarkan hasil penelitian dan pengembangan yang telah dilakukan, maka dapat disarankan:

Pertama, guru dapat menerapkan strategi pembelajaran berbasis masalah pada proses pembelajaran agar dapat meningkatkan keterampilan berpikir kritis dan kemampuan pemecahan masalah peserta didik.

Kedua, peneliti lain dapat melanjutkan penelitian ini dengan melakukan kajian pada aspek yang lain.

\section{DAFTAR RUJUKAN}

Abidin, Y. 2014. Desain Sistem Pembelajaran dalam Konteks Kurikulum 2013. Bandung: PT Refika Aditama.

Alfana, Mila, dkk. 2015. Pengembangan

Lembar Kegiatan Siswa IPA

Terpadu Berbasis Konstruktivisme

Tema Energi Dalam Kehidupan

Untuk Siswa SMP. Unnes

Science Education Journal,

(Online), (Universitas Negeri

Semarang, Diakses pada tanggal 15 Februari 2018).

Amir, M. \& Taufik. 2009. Inovasi Pendidikan Melalui Problem Based 
Learning. Jakarta: Kencana Prenada Media Group.

Daryanto., \& Dwicahyo, A. 2014. Pengembangan Perangkat Pembelajaran. Yogyakarta:

Gava Media.

Hidayat, M, F. 2013. Pembelajaran Berbasis Masalah untuk Meningkatkan Hasil Belajar Biologi Pada Tingkat SMA. Makalah disajikan dalam Seminar Nasional X Pendidikan Biologi FKIP UNS, Solo.

Hobri. $2009 . \quad$ Metodologi PenelitianPengembangan (Aplikasi Pada penelitian Pendidikan Matematik). Jember : Pena Salsabila.

Hosnan. 2014. Pendekatan Saintifik dan Kontekstual dalam Pembelajaran Abad 21. Bogor: Ghalia Indonesia.

Irmayanti. 2015. Pengaruh Penilaian Portofolio dalam Model Pembelajaran Advanced Organizer dan Kemampuan Awal terhadap Pemahaman Konsep dan Motivasi Belajar Kimia Peserta didik kelas XI SMA Negeri 12 Makassar. Tesis. Tidak diterbitkan. Makassar: PPs UNM.

Khotim, Hikmatun, Nurul, dkk. 2015. Pengembangan Modul Kimia Berbasis Masalah Pada Materi Asam Basa. Jurnal Chemistry in Education, (Universitas Negeri Semarang, Diakses pada tanggal 15 Februari 2018).

Nurdin, 2007. Model Pembelajaran Matematika yang Menumbuhkan

Kemampuan Metakognitif untuk Menguasai Bahan Ajar. Disertasi. Tidak diterbitkan. Surabaya: PPs UNESA.

Pusat Penilaian Pendidikan Balitbang Kemdikbud. 2018. Nilai Ujian Nasional. Jakarta: Puspendik Balitbang Kemdikbud.

Riduwan, 2010. Metode dan Teknis Menyusun Tesis. Bandung :

Alfabeta
Riyanto, Y. (2009). Paradigma Baru Pembelajaran. Jakarta: Kencana Prenada.

Rosyada, D. (2004). Paradigma Pendidikan Demokratis Sebuah Modal Masyarakat dalam Penyelenggaraan Pendidikan. Jakarta: Prenada Media.

Rusmono. 2012. Srategi Pembelajaran dengan Problem Based Learning Itu perlu. Jakarta: Ghalia Indonesia.

Sadiman, A.S. 1986. Media Pendidikan, Pengertian, Pengembangan, dan Pemanfaatannya. Jakarta: CV. Rajawali.

Sanjaya, W. 2006. Strategi Pembelajaran Berorientasi Standar Proses Pendidikan. Jakarta: Kencana Prenada Media Group.

Sari, D.D. 2012. Penerapan Model Problem Based Learning (PBL) Untuk Meningkatkan Kemampuan Berpikir Kritis Peserta Didik Pada Pembelajaran IPA Kelas VIII SMP Negeri 5 Sleman Tahun Ajaran 2012. Skripsi. Tidak diterbitkan. Yogyakarta: Program Studi Pendidikan IPA UNY.

Sugiyono. 2011. Metode Penelitian Pendidikan (Pendekatan Kuantitatif, Kualitatif, dan $R \& D)$. Bandung: Alfabeta

Suparman, M. A. 2014. Desain Instruksional Modern. Jakarta: Erlangga.

Surya, M. 2015. Strategi Kognitif dalam Proses Pembelajaran. Bandung: Alfabeta.

Trianto. (2009). Mendesain Model Pembelajaran Inovatif-Progresif. Jakarta:Kencana Prenada Media Group.

Wahyuni, S. 2015. Pengembangan bahan Ajar IPA untuk meningkatkan kemampuan berpikir kritis siswa SMP. Jurnal materi dan pembelajaran fisika, (Online), Volume 5 nomor 2, (Universitas 
Chemistry Education Review, Pendidikan Kimia PPs UNM, 2019, Vol.2, No.2 (111-126)

Jember, Diakses tanggal

10 Oktober 2017).

Wena, M. (2009). Strategi Pembelajaran

Inovatif Kontemporer. Jakarta:

Bumi Aksara.

Yaumi, M. 2013. Prinsip-prinsip Desain

Pembelajaran Disesuaikan dengan

Kurikulum 2013. Edisi Kedua.

Jakarta: Kencana. 